\title{
Base-line Data on Herpetofaunal Diversity in the Chandrapur District of Maharashtra, India
}

Dinesh D. Khate ${ }^{1}$ and Kiran Bawaskar ${ }^{2}$

${ }^{1}$ Behind State Bank colony, In front of Biyani petrol pump, Tadoba road Tukum, Chandrapur (dineshkhate@gmail.com)

${ }^{2}$ Department of Chemistry Narasamma College, kiran nagar, Amravati 444601 (ksbbiochem@gmail.com)

Photographs by the senior author except as indicated.

$\mathrm{R}$ eptiles and amphibians play key roles in both aquatic and terrestrial ecosystems (e.g., Schneider et al 2001; McCallum 2007). Among other attributes, they are important components of food chains, can serve to control insect pests, and are good ecological indicators. Substantial declines in herpetofaunal abundance and diversity are of considerable concern among conservation biologists and more studies of amphibian and reptilian populations are necessary to better understand the overall decline in biodiversity.

Chandrapur District (Fig. 1) is located on the eastern edge of Maharashtra in the Nagpur Division, where it comprises the eastern part of the "Vidarbha" Region. The Anandvan and Tadoba-Andhari Tiger Reserve is located in the Chandrapur District. The entire district is within the

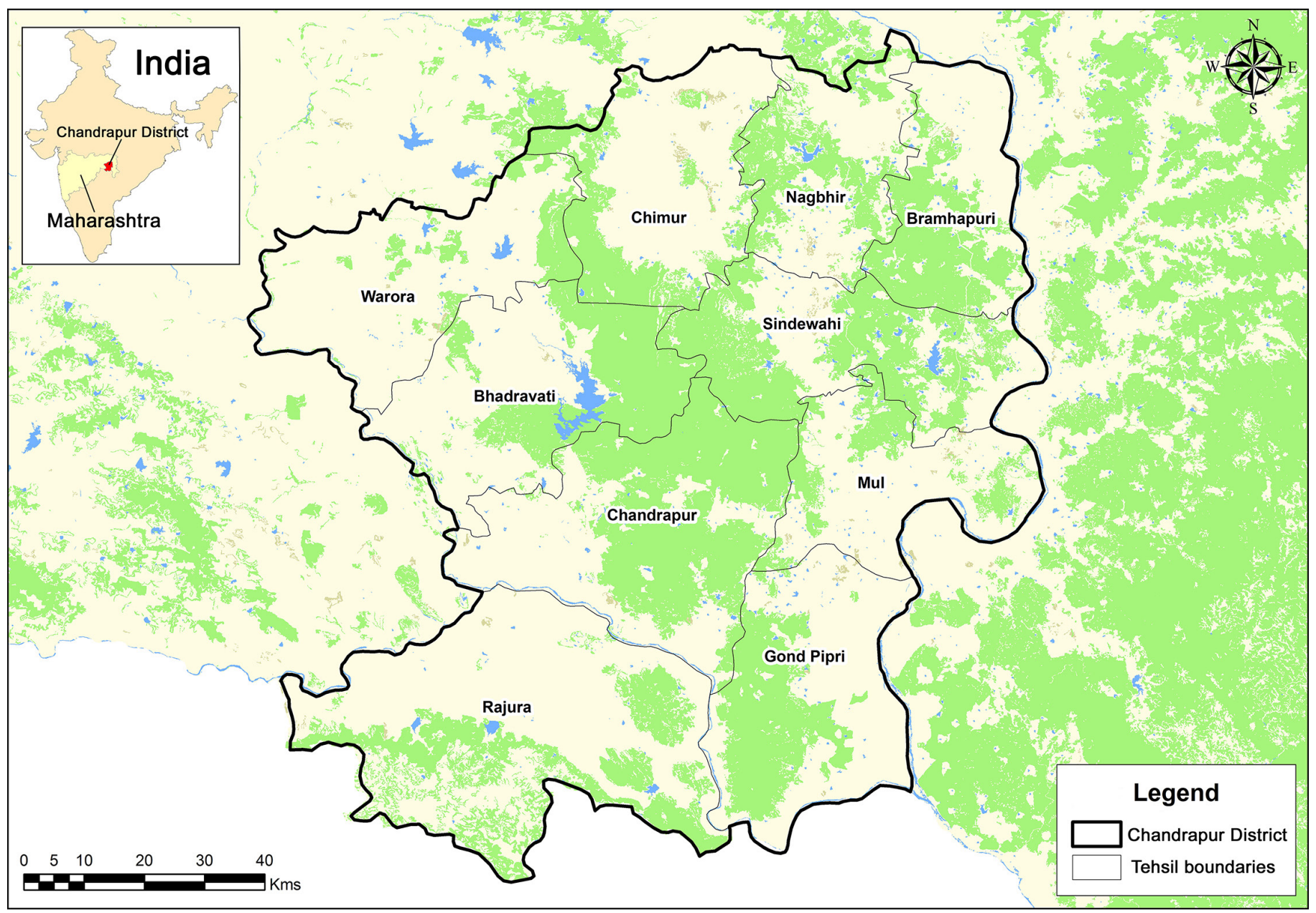

Fig. 1. Map of the Chandrapur District, Maharashtra, India, and its tehsils (administrative units). 

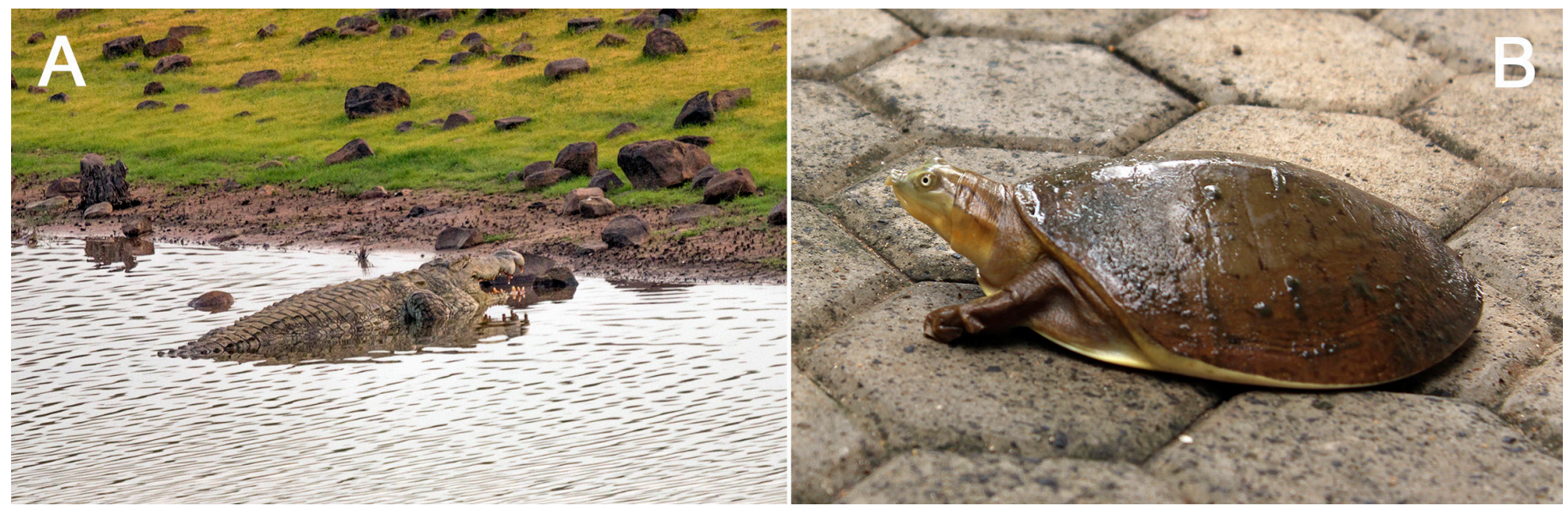

Fig. 2. Selected species encountered during herpetofaunal surveys of the Chandrapur District, Maharashtra, India: (A) Mugger Crocodile (Crocodylus palustris). Photograph by Amit Wahale. (B) Indian Softshell Turtle (Lissemys punctata). Photograph by Shashank Moharkar.

Table 1. Species encountered during herpetofaunal surveys of the Chandrapur District, Maharashtra, India. Common names are from Uetz et al. (2019) and Frost (2019). Habitats based on observations during surveys: $\mathrm{Aq}=$ aquatic; $\mathrm{Tr}=$ terrestrial; $\mathrm{Ar}=\operatorname{arboreal} ; \mathrm{Sr}=$ stony and rocky. Status based on frequencies of encounters during surveys: $\mathrm{C}=$ common; $\mathrm{U}=$ uncommon; $\mathrm{O}=$ occasional; $\mathrm{R}=$ rare.

Species

Habitat

Status

Reptilia: Crocodylia

Family Crocodilidae

Crocodylus palustris (Lesson 1831) Mugger Crocodile

Aq, $\operatorname{Tr}$

$\mathrm{R}$

\section{Reptilia: Testudines}

Family Testudinidae

Geochelone elegans (Schoepff 1795) Indian Star Tortoise

$\operatorname{Tr}$

$\mathrm{R}$

\section{Family Trionychidae}

Lissemys punctata (Bonnaterre 1789) Indian Softshell Turtle

Nilssonia leithii (Gray 1872) Leith’s Softshell Turtle

$\begin{array}{ll}\text { Aq, } \operatorname{Tr} & \mathrm{U} \\ \mathrm{Aq}, \mathrm{Tr} & \mathrm{O}\end{array}$

\section{Reptilia: Squamata (lizards)}

\section{Family Agamidae}

Calotes versicolor (Daudin 1812) Oriental Garden Lizard

Psammophilus blanfordanus (Stoliczka 1871) Blanford's Rock Agama

\begin{tabular}{cc}
$\mathrm{Tr}, \mathrm{Ar}$ & $\mathrm{C}$ \\
\hline $\mathrm{Tr}, \mathrm{Ar}, \mathrm{Sr}$ & $\mathrm{C}$ \\
$\mathrm{Tr}, \mathrm{Sr}$ & $\mathrm{C}$ \\
\hline
\end{tabular}

Sitana spinaecephalus (Deepak, Vyas, and Giri 2016) Fan-throated Lizard

\section{Family Chamaeleonidae}

Chamaeleo zeylanicus (Laurenti 1768) Indian Chameleon

Ar

\section{Family Gekkonidae}

Cyrtodactylus varadgirii Agarwal, Mirza, Pal, Maddock, Mishra, and Bauer 2016 Giri’s Geckoella

$\operatorname{Tr} \quad \mathrm{O}$

Hemidactylus cf. parvimaculatus Deraniyagala 1953 Spotted House Gecko

Hemidactylus flaviviridis Rüppell 1835 Northern House Gecko

Hemidactylus giganteus (Stoliczka 1871) Giant Leaf-toed Gecko

Hemidactylus leschnaultii (Dumeril and Bibron 1836) Bark Gecko

Hemidactylus triedrus (Daudin 1802) Termite Hill Gecko

Ar, $\mathrm{Tr}, \mathrm{Sr} \quad \mathrm{C}$

Hemidactylus gracilis (Blanford 1870) Graceful Leaf-toed Gecko

\begin{tabular}{cc}
$\mathrm{Ar}, \mathrm{Sr}$ & $\mathrm{C}$ \\
$\mathrm{Ar}, \mathrm{Sr}$ & $\mathrm{R}$ \\
$\mathrm{Ar}$ & $\mathrm{U}$ \\
\hline $\mathrm{Tr}, \mathrm{Sr}$ & $\mathrm{U}$ \\
\hline $\mathrm{Tr}$ & $\mathrm{U}$ \\
\hline
\end{tabular}




\section{Family Lacertidae}

Ophisops jerdonii (Blyth 1853) Jerdon's Snake-eyed Lacerta

$\mathrm{Tr}, \mathrm{Sr}$

Family Mabuyidae

Eutropis carinata (Schneider 1801) Golden Skink

$\mathrm{Tr}, \mathrm{Sr}$

C

Eutropis macularia (Blyth 1853) Bronze Grass Skink

Family Lygosomidae

\begin{tabular}{cc} 
Tr, $\boldsymbol{S r}$ & $\mathbf{C}$ \\
\hline $\operatorname{Tr}$ & $\mathrm{U}$ \\
\hline $\operatorname{Tr}$ & $\mathrm{U}$ \\
\hline
\end{tabular}

Lygosoma lineata (Gray 1839) Lined Supple Skink

Lygosoma punctata (Gmelin 1799) Spotted Supple Skink

\section{Family Varanidae}

Varanus bangalensis (Daudin 1802) Bengal Monitor

\section{Reptilia: Squamata (snakes)}

\section{Family Typhlopidae}

Indotyphlops braminus (Daudin 1803) Brahminy Blindsnake

Tr, Sr C

Grypotyphlops acutus (Duméril and Bibron 1844) Beaked Wormsnake

$\operatorname{Tr}$

\section{Family Erycidae}

Eryx conicus (Schneider 1801) Common Sand Boa

$\operatorname{Tr} \quad \mathrm{C}$

Eryx johnii (Russell 1801) Red Sand Boa

$\operatorname{Tr}$

U

\section{Family Pythonidae}

Python molurus (Linnaeus 1758) Indian Rock Python

$\mathrm{Aq}, \mathrm{Tr}, \mathrm{Sr}, \mathrm{Ar} \quad \mathrm{U}$

\section{Family Ahaetuliidae}

Ahaetulla nasuta (Lacepède 1789) Common Vinesnake

Dendrelaphis tristis (Daudin 1803) Bronzeback Treesnake

$\begin{array}{cc}\mathrm{Ar} & \mathrm{U} \\ \mathrm{Sr}, \mathrm{Tr} & \mathrm{C}\end{array}$

\section{Family Colubridae}

Argyrogena fasciolata (Shaw 1802) Banded Racer

Boiga trigonata (Schneider 1802) Common Catsnake

Boiga forsteni (Duméril, Bibron, and Duméril 1854) Forsten's Catsnake

$\begin{array}{cc}\mathrm{Tr}, \mathrm{Sr} & \mathrm{U} \\ \mathrm{Ar}, \mathrm{Sr}, \mathrm{Tr} & \mathrm{U}\end{array}$

Boiga flaviviridis Vogal and Ganesh 2013 Common Trinket Snake

Ar, $\operatorname{Tr} \quad \mathrm{O}$

Coelognathus helena (Daudin 1803) Trinket Snake

$\mathrm{Tr}, \mathrm{Sr}$

$\mathrm{C}$

Coronella brachyura (Günther 1866) Indian Smooth Snake

$\mathrm{Tr}, \mathrm{Sr} \quad \mathrm{U}$

Elachistodon westermanni (Reinhardt 1863) Indian Egg-Eater

Lycodon aulicus (Linnaeus 1758) Common Wolfsnake

Lycodon flavomaculatus (Wall 1907) Yellow-spotted Wolfsnake

Lycodon striatus (Shaw 1802) Barred Wolfsnake

Oligodon arnensis (Shaw 1802) Common Banded Kukri Snake

Oligodon taeniolatus (Jerdon1853) Russell's Kukri Snake

Ptyas mucosa (Linnaeus 1758) Indian Rat Snake

$\operatorname{Tr} \quad \mathrm{O}$

$\mathrm{Tr}, \mathrm{Sr} \quad \mathrm{O}$

\section{Family Lamprophiidae}

Psammophis longifrons (Boulenger 1897) Stout Sand Snake

\begin{tabular}{cc} 
Ar, Tr, Sr & C \\
\hline $\operatorname{Tr}$ & $\mathrm{O}$ \\
\hline $\operatorname{Tr}$ & $\mathrm{C}$ \\
$\mathrm{Tr}$ & $\mathrm{C}$ \\
\hline $\mathrm{Tr}, \mathrm{Sr}$ & $\mathrm{U}$ \\
\hline $\mathrm{Aq}, \mathrm{Tr}, \mathrm{Sr}, \mathrm{Ar}$ & $\mathrm{C}$
\end{tabular}

\section{Family Natricidae}

Amphiesma stolatum (Linnaeus 1758) Striped Keelback

Atretium schistosum (Daudin 1803) Olive Keelback

$\mathrm{Ar}, \mathrm{Tr}, \mathrm{Sr}$

Fowlea piscator (Schneider 1799) Checkered Keelback

Rhabdophis plumbicolor (Cantor 1839) Green Keelback

$\begin{array}{cc}\operatorname{Tr} & \mathrm{C} \\ \mathrm{Tr} & \mathrm{O} \\ \mathrm{Aq}, \mathrm{Tr} & \mathrm{C} \\ \mathrm{Tr} & \mathrm{O}\end{array}$




\section{Family Sibynophiidae}

Sibynophis subpunctatus (Duméril Bibron, and Duméril 1854) Dumeril's Black-headed Snake

$\operatorname{Tr}$

$\mathrm{O}$

Family Viperidae

Daboia russelii (Shaw and Nodder 1797) Russell's Viper

$\operatorname{Tr}, \mathrm{Sr} \quad \mathrm{C}$

Echis carinatus (Schneider 1801) Saw-scaled Viper

$\mathrm{Tr}, \mathrm{Sr}$

\section{Family Elapidae}

Bungarus caeruleus (Schneider 1801) Common Krait

Bungarus fasciatus (Schneider 1801) Banded Krait

Calliophis melanurus (Shaw 1802) Slender Coralsnake

Naja naja (Linnaeus 1758) Indian Cobra

\begin{tabular}{cc}
$\mathrm{Tr}, \mathrm{Sr}$ & $\mathrm{C}$ \\
$\mathrm{Tr}$ & $\mathrm{R}$ \\
$\mathrm{Tr}$ & $\mathrm{R}$ \\
\hline $\mathrm{Ar}, \mathrm{Tr}, \mathrm{Sr}$ & $\mathrm{C}$ \\
\hline
\end{tabular}

\section{Amphibia: Anura \\ Family Bufonidae}

Duttaphrynus melanostictus (Schneider 1799) Common Indian Toad

\begin{tabular}{cc} 
Tr, Sr, Aq & C \\
\hline Tr, Sr, Aq & C \\
\hline Tr, Sr, Aq & $\mathrm{O}$ \\
\hline
\end{tabular}

Duttaphrynus stomaticus (Lütken 1864) Marbled Toad

Duttaphrynus scaber (Schneider 1799) Schneider's Toad

\section{Family Microhylidae}

Microhyla ornata (Duméril and Bibron 1841) Ornate Narrow-mouthed Frog

$\mathrm{Tr}, \mathrm{Sr}, \mathrm{Aq} \quad \mathrm{C}$

Microhyla rubra (Jerdon 1854) Red Narrow-mouthed Frog

Aq, $\operatorname{Tr} \quad \mathrm{O}$

Uperodon taprobanicus (Parker 1934) Painted Frog

Uperodon variegatus (Stoliczka 1872) White-bellied Pug-snouted Frog

Tr, Sr, Aq, Ar U

Uperodon globulosus (Günther 1864) Indian Globular Frog

$\mathrm{Tr}, \mathrm{Sr}, \mathrm{Aq} \quad \mathrm{R}$

Uperodon systomus (Schneider 1799) Marbled Balloon Frog

$\mathrm{Tr}, \mathrm{Aq} \quad \mathrm{R}$

\section{Family Dicroglossidae}

Fejervarya limnocharis (Gravenhorst 1829) Indian Cricket Frog

$\operatorname{Tr}, \mathrm{Aq}$

$\mathrm{R}$

Euphlyctis cyanophlyctis (Schneider 1799) Skittering Frog

Hoplobatrachus tigerinus (Daudin 1803) Indian Bullfrog

Tr, Aq C

Hoplobatrachus crassus (Jerdon 1853) Jerdon's Bullfrog

$\mathrm{Tr}, \mathrm{Aq}, \mathrm{Sr}$

Sphaerotheca breviceps (Schneider 1799) Indian Burrowing Frog

Tr, Aq C

Sphaerotheca dobsonii (Boulenger 1882) Dobson's Burrowing Frog

$\mathrm{Tr}, \mathrm{Aq} \quad \mathrm{U}$

\section{Family Ranidae}

Hydrophylax bahuvistara (Padhye, Jadhav, Modak, Nameer, and Dahanukar 2015) Wide-spread Fungoid Frog

Family Rhacophoridae

Polypedates maculatus (Gray 1830) Common Treefrog

$\mathrm{Tr}, \mathrm{Sr}, \mathrm{Aq} \quad \mathrm{C}$




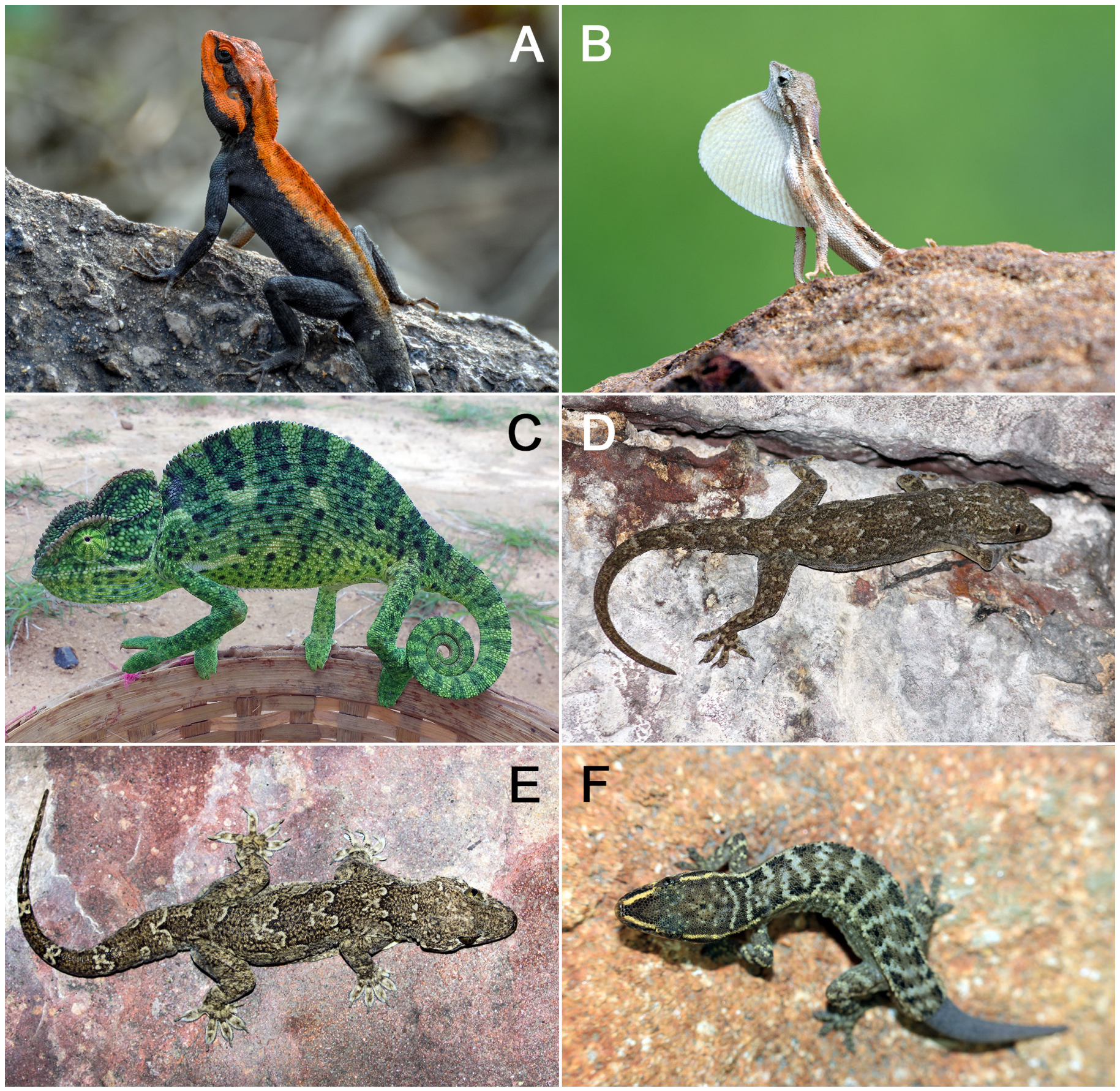

Fig. 3. Selected species encountered during herpetofaunal surveys of the Chandrapur District, Maharashtra, India: (A) Blanford's Rock Agama (Psammophilus blanfordanus). (B) Fan-throated Lizard (Sitana spinaecephalus). (C) Indian Chameleon (Chamaeleo zeylanicus). (D) Northern House Gecko (Hemidactylus flaviviridis). (E) Giant Leaf-toed Gecko (Hemidactylus giganteus). (F) Graceful Leaf-toed Gecko (Hemidactylus gracilis).

Godavari Basin, which is drained by the major tributaries of the Godavari River (i.e., the Penganga, Wainganga, and Wardha Rivers). Average annual temperature is $27.2^{\circ} \mathrm{C}$, but summer temperatures can reach nearly $50^{\circ} \mathrm{C}$ and winter temperatures can be as low as $8{ }^{\circ} \mathrm{C}$; average annual rainfall is $1,280 \mathrm{~mm}$ (https://en.climate-data.org/asia/india/maharashtra/chandrapur-24355/).

Only a few publications address the herpetofaunal diversity in the general area. Bawaskar and Bawaskar (2016) documented 58 species of herpetofauna from the Khamgaon District, Buldhana in central India. Ingle et al. (2014) observed 21 species of snakes from Malegaon Tehsil of the Washim District of Maharashtra. Joshi et al. (2014) recorded 35 species of ophidians in the Vidarbha Region. Bhandarkar et al. (2012) listed 59 species of amphibians and reptiles from Navegaon National Park, Gondia District, Maharashtra. Joshi (2011) recorded 22 species of snakes in the Buldhana District. Nande and Deshmukh (2007) observed 32 species 


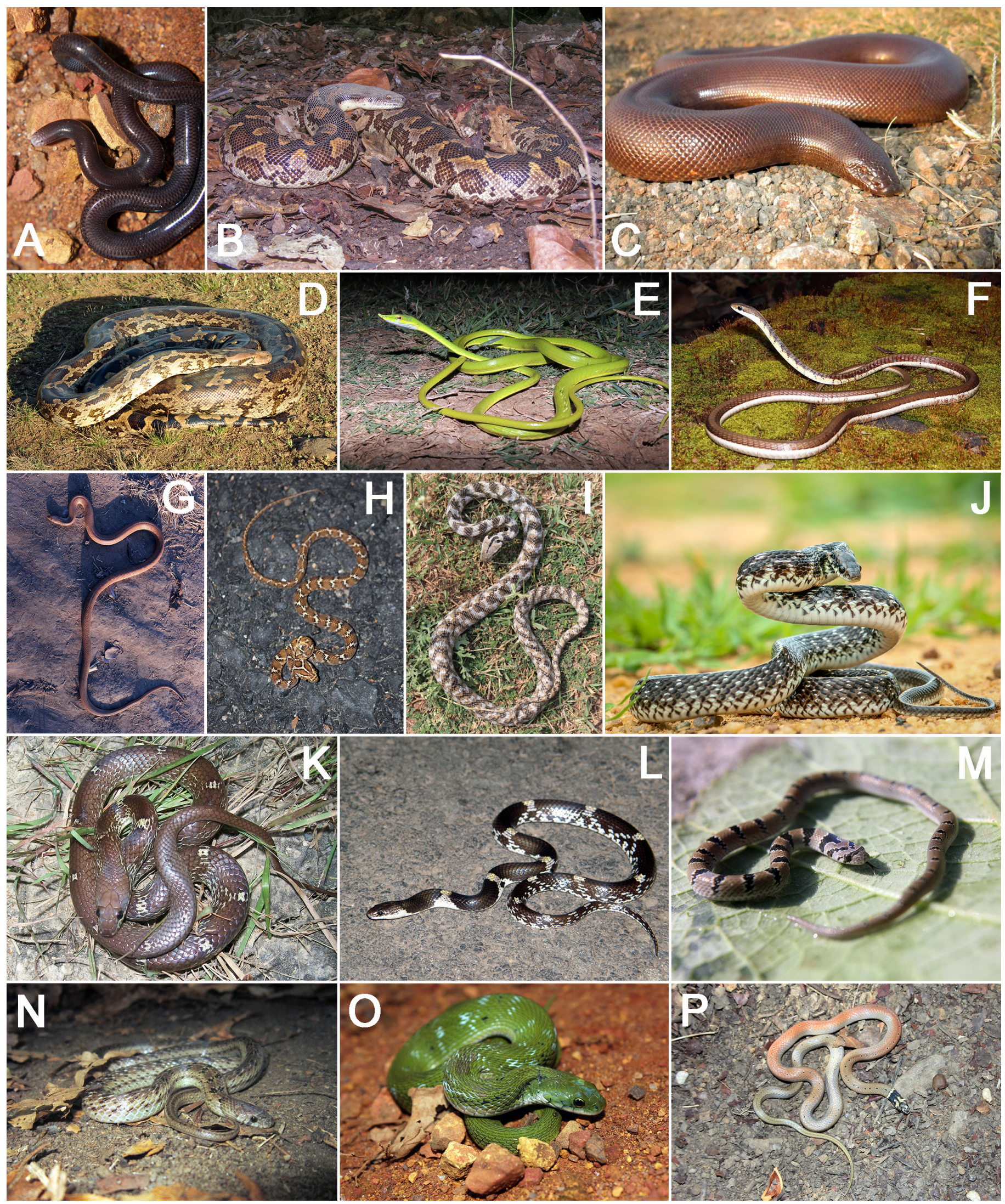

Fig. 4. Selected species encountered during herpetofaunal surveys of the Chandrapur District, Maharashtra, India: (A) Brahminy Blindsnake (Indotyphlops braminus). (B) Common Sand Boa (Eryx conicus). (C) Red Sand Boa (Eryx johnii). (D) Indian Rock Python (Python molurus). (E) Common Vinesnake (Ahaetulla nasuta). (F) Bronzeback Treesnake (Dendrelaphis tristis). (G) Banded Racer (Argyrogena fasciolata). (H) Common Catsnake (Boiga trigonata). (I) Forsten's Catsnake (Boiga forsteni). (J) Indian Egg-Eater (Elachistodon westermanni). (K) Common Wolfsnake (Lycodon aulicus). (L) Barred Wolfsnake (Lycodon striatus). (M) Common Banded Kukri Snake (Oligodon arnensis). (N) Russell's Kukri Snake (Oligodon taeniolatus). (O) Green Keelback (Rhabdophis plumbicolor). (P) Dumeril's Black-headed Snake (Sibynophis subpunctatus). 

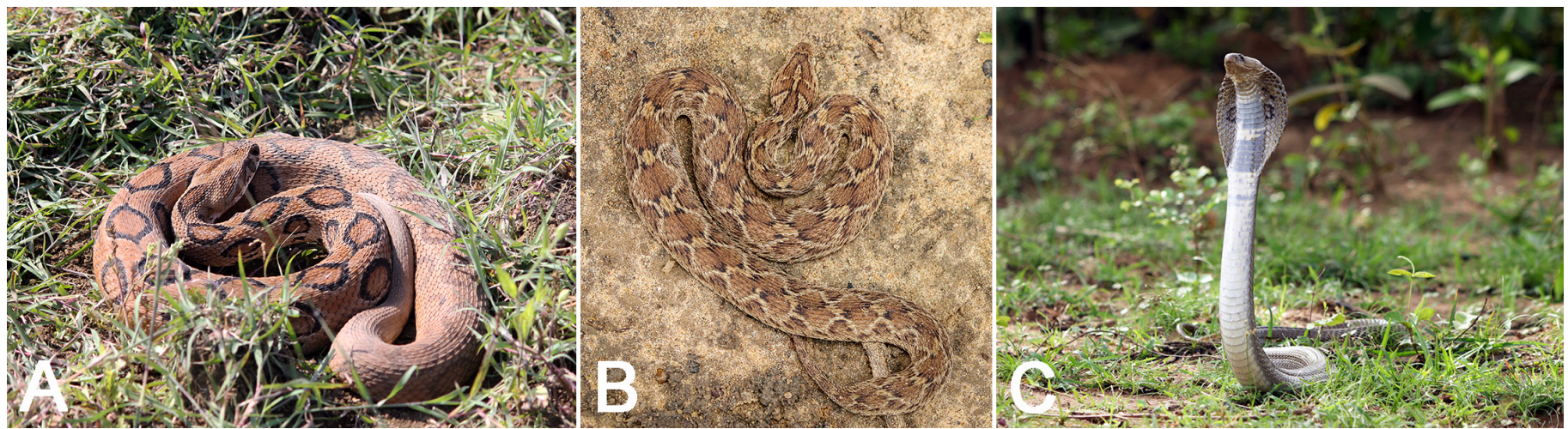

Fig. 5. Selected species encountered during herpetofaunal surveys of the Chandrapur District, Maharashtra, India: (A) Russell's Viper (Daboia russelii). (B) Saw-scaled Viper (Echis carinatus). (C) Indian Cobra (Naja naja).
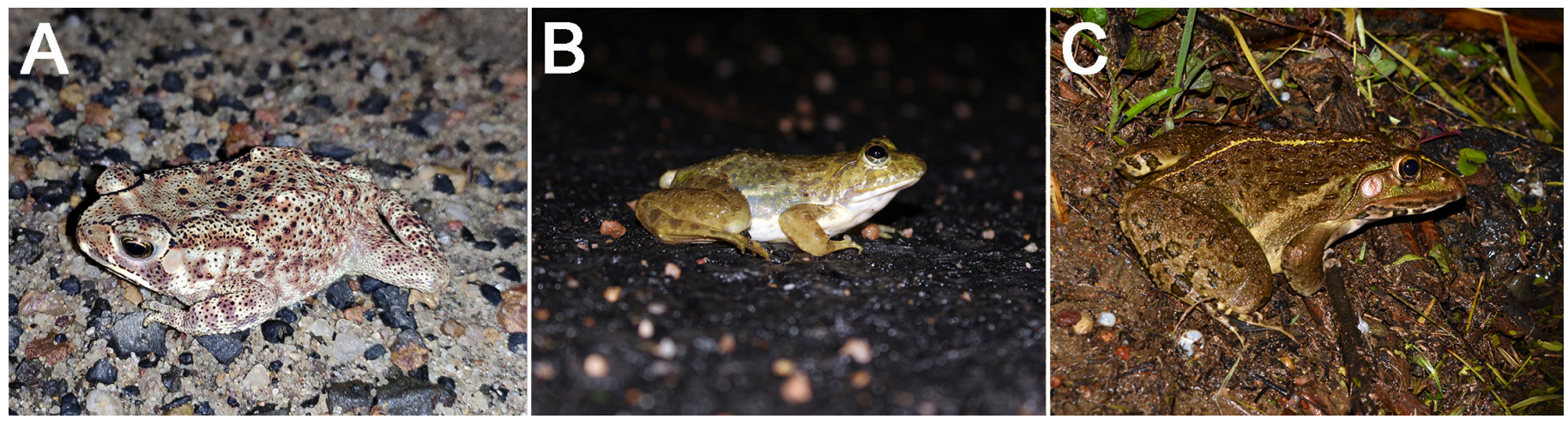

Fig. 6. Selected species encountered during herpetofaunal surveys of the Chandrapur District, Maharashtra, India: (A) Common Indian Toad (Duttaphrynus melanostictus). (B) Skittering Frog (Euphlyctis cyanophlyctis). (C) Indian Bullfrog (Hoplobatrachus tigerinus).

of snakes from Amravati, which includes Melghat. Wadatkar (2003) studied 12 species of snakes from the Amravati University campus.

Within the Chandrapur District, Kumbhar et al. (2013) documented 30 species of reptiles from the Tadoba-Andhari Tiger Reserve and Harney (2011) observed 17 species of snakes from Bhadravati. We herein document base-line data on the herpetofauna of the Chandrapur District in the Vidarbha Region of Maharashtra.

\section{Methods}

Using visual field techniques for herpetofaunal community analysis (Campbell and Christman 1982), we conducted surveys by day and night throughout the Chandrapur District from 2010 to 2018. Habitats surveyed included forests, scrublands, grasslands, marshes, plantations and agricultural land, roadsides, and the margins of farms and urban areas of various sizes. We turned rocks and other surface cover, cleared leaf litter, peeled loose bark on trees and fallen logs, and examined burrows. We also collected data from snake rescuers, wildlife enthusiasts, and local people who had observed or captured amphibians and reptiles. For identification of species, we employed various references, including Günther (1864), Boulenger (1890), Smith (1931, 1935a, 1935b, 1943), Daniel (2002), Khaire (2008), and Whitaker and Captain (2008).

\section{Results}

We recorded a total of 70 species (Table 1; Figs. 2-6) in 25 families and 50 genera. Of these, 53 species were reptiles belonging to 20 families and 39 genera and 17 species were amphibians in 5 families and 9 genera. The most frequently encountered species of reptiles were Calotes versicolor, Hemidactylus cf. parvimaculatus, $H$. flaviviridis, Eutropis carinata, E. macularia, Lycodon aulicus, Ptyas mucosa, Fowlea piscator, Naja naja, and Daboia russellii, and the most frequently encountered species of amphibians were Duttaphrynus melanostictus, Microhyla ornata, Euphlyctis cyanophlyctis, Hoplobatrachus tigerinus, and Sphaerotheca breviceps. Rarely encountered species (Fig. 7) included Crocodylus palustris (Irai and Chargaon Dams), Geochelone elegans (Kothari and Rajura), Coronella brachyura (Bhadravati), Calliophis melanurus (Warora), Cyrtodactylus varadgirii (Bhadravati), Hemidactylus giganteus (Manikgarh Fort), Boiga westermanni (Padmapur and Gad Chandur), Psammophis longifrons (Mul), Atretium schistosum (Mul and Brahmapuri), Bungarus fasciatus (Brahmapuri), Uperodon variegatus (Sitarampeth), Uperodon systoma (Valani), and Uperodon globulosus (Sat Bahini Hill). 


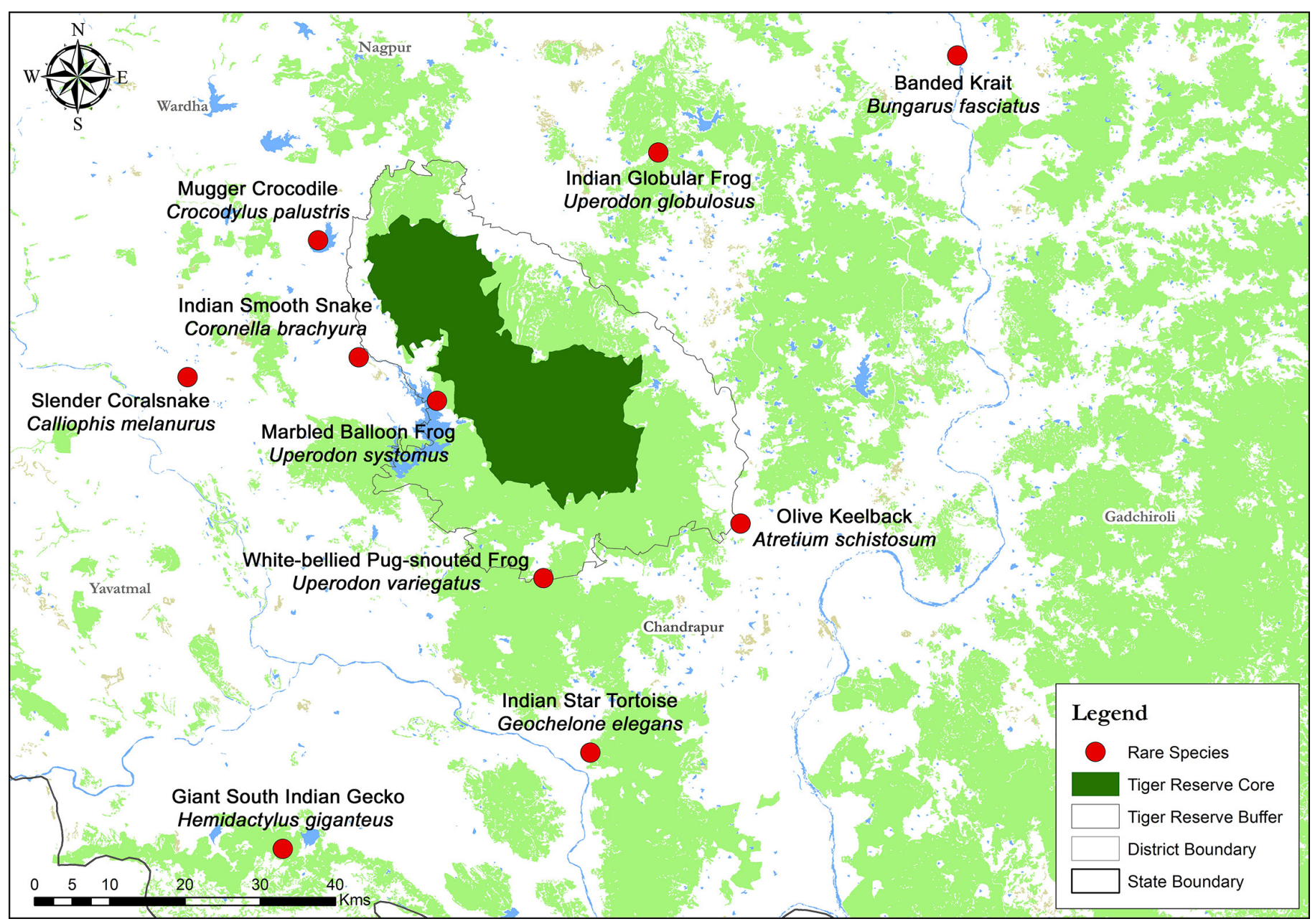

Fig. 7. Locations of rarely encountered herpetofaunal species (red circles) in the Chandrapur District, Maharashtra, India. The core (dark green) and buffer zone of the Tadoba-Andhari Tiger Reserve are indicated.

\section{Acknowledgements}

We thank Ankur Kali and Sachin Wazalwar for assistance with the identification of species and valuable support. We also are grateful for the assistance of snake rescuers and the wildlife community, including Pankaj Rangari, Jitendra Nomulwar, Kulmethe Khobaragde, Avi Kakade, Rahul Chilgirwar, Satish Tayde, Pappi Yadav, Sheetal Kolhe, Prashant Shrikotwar, Vaibhaw Tannirwar, Pintu Uike, Vandip Rode, Nikhil Zade, Kiran Gedam, Pranay Magre, Deepak Sonkusre, Sainath Chaudhari, Umesh Zire, Adity Dharne, Tanmay Zire, Nayan Kumbhare, Krupal Nakade, Vicky Petkar, and Nayan Kumbhare.

\section{Literature Cited}

Bawaskar P.S. and K. Bawaskar. 2016. Herpetofaunal diversity from Khamgaon, District Buldhana (M.S.) Central India. International Journal of Life Sciences 4: 412-418.

Bhandarkar W.R., G.T. Paliwal, S.V. Bhandarkar, and A.A. Kali. 2012. Herpetofaunal diversity at Navegaon National Park, Distt. Gondia Maharashtra. International Journal for Environmental Rehabilitation and Conservation III (1): 42-49.

Boulenger, G.A. 1890. The Fauna of British India including Ceylon and Burma: Reptilia and Batrachia. Taylor and Francis, London, United Kingdom.
Campbell, H.W. and S.P. Christman. 1982. Field techniques for herpetofaunal community analysis, pp. 193-200. In: N.J. Scott, Jr. (ed.), Herpetological Communities. Wildlife Research Report 13, U.S. Fish and Wildlife Service, Washington, D.C.

Daniel, J.C. 2002. The Book of Indian Reptiles and Amphibians. Bombay Natural History Society and Oxford University Press, Mumbai, India.

Frost, D.R. 2019. Amphibian Species of the World: An Online Reference. Version 6.0. American Museum of Natural History, New York, New York. <http:// research.amnh.org/herpetology/amphibia/index.html>.

Günther, A. 1864. The Reptiles of British India. Oxford \& IBH Publishing Co., New Delhi, India.

Harney, N.V. 2011. Studies on snakes of Bhadravati, District Chandrapur (M.S.) India. Online International Interdisciplinary Research Journal 1(3): 12-17.

Ingle P., S. Bali, and J. Khandagale. 2014. Preliminary survey of snake diversity from Malegaon Tehsil of Washim. District World Journal of Zoology 9(2): 134-137.

Joshi P.S. 2011. A preliminary survey on the snakes of Buldhana District, Maharashtra. Golden Research Thoughts 1(2): 73-74.

Joshi P.S., V.T. Tantarpale, and K.M. Kulkarni. 2014. A review of ophidian studies in Vidarbha region (M.S.) India. Science Research Reporter 4: 167-170.

Kumbhar A.S., B. Yele, S. Shinde, and A. Dashahare. 2013. Observation on reptilian fauna of Tadoba-Andhari Tiger Reserve, Maharashtra, India. World Journal of Zoology 8: 397-400.

Mc Callum, M.L. 2007. Amphibian decline or extinction? Current declines dwarf background extinction rate. Journal of Herpetology 41: 483-491.

Nande, R. and S. Deshmukh. 2007. Snakes of Amravati District including Melghat, Maharashtra. With important records of the Indian Egg-eater, montane trin- 
ket snake and Indian smooth snake. Zoos' Print Journal 22: 2920-2974.

Schneider, R.L., M.E. Krasny, and S.J Morreale. 2001. Hands-on herpetology: Exploring Ecology and Conservation. NSTA Press, Arlington, Virginia.

Smith, M.A. 1931. The Fauna of British India including Ceylon and Burma. Reptilia and Amphibia. Vol. I.-Loricata, Testudines. Taylor and Francis, London, United Kingdom.

Smith, M.A. 1935a. The Fauna of British India including Ceylon and Burma. Reptilia and Amphibia. Vol. II.-Sauria. Taylor and Francis, London, United Kingdom.

Smith, M.A. 1935b. Some notes on the monitors. Journal of the Bombay Natural
History Society 35: 615-619.

Smith, M.A. 1943. The Fauna of British India Ceylon and Burma, Including the Whole of the Indo-Chinese Sub-region. Reptilia and Amphibia. Vol. III.Serpentes. Taylor and Francis, London, United Kingdom.

Uetz, P., P. Freed, and J. Hošek (eds.). 2019. The Reptile Database. <http://www. reptile-database.org>.

Wadatkar, J.S. 2003. Herpetofauna of the Amravati university campus. Maharashtra. Zoos' Print Journal 19: 1381-1382.

Whitaker, R. and A. Captain. 2008. Snakes of India -The Field Guide. Draco Books, Chennai, India. 